\title{
Summer Grazing of Sagebrush-Grass Range by Sheep
}

\author{
R.O. HARNISS AND H.A. WRIGHT
}

\begin{abstract}
Sagebrush-grass range normally grazed in the spring and fall can be grazed in the summer to provide a maintenance ration for ewes if their lambs are weaned early. Moderate grazing (57-99 sheep days/ha) in early or late summer did not change vegetative composition or yields. Heavy grazing (185-198 sheep days/ha) in the early summer decreased yields of grasses and the cushion-forb Hoods phlox. Late summer grazing did not change the grass or forb yields. Sagebrush yields increased in the sagebrush subtype where balsamroot was abundant under early summer grazing.
\end{abstract}

Each decade since the early 1900's, sheep numbers grazing traditional high mountain summer ranges have been declining. The major reasons for decline have been to lessen watershed damage and to avoid losses caused by predators or poor herders. Because of these and sheepmen's needs to maximize wool and lamb production, we decided to investigate the use of traditional spring-fall sagebrush-grass range in the summer to maintain ewes that had their lambs weaned early. In this paper we are reporting the effects of summer grazing on two sagebrush community subtypes and ewe weight responses during the summer season. Doyle et al. (in press) reported on breed weights, longevity, reproductivity, wool production, and lamb production between comparable groups of sheep sent to sagebrush-grass and high mountain summer ranges.

\section{Study Area and Methods}

The study was conducted on the U.S. Sheep Experiment Station at Dubois, Idaho, at an elevation of $1,646 \mathrm{~m}$. Average annual precipitation is $28 \mathrm{~cm}$ with peaks in January due to snow and May and June due to rain. Topography is level to undulating with varying amounts of lava outcrops in all of the study pastures. The vegetation consists of threetip sagebrush (Artemisia tripartita) with an understory mixture of grasses and forbs. Two subtypes of the sagebrush-grass community are identifiable by the amount of arrowleaf balsamroot (Balsamorhiza sagitrata) present. The subtype with balsamroot (balsamroot subtype) is generally positioned in the swales. The subtype without balsamroot (pricklygilia subtype) generally has more granite pricklygilia (Leptodactylon pungens) and is generally positioned on the lava outcrops.

Three treatments (early summer grazing, late summer grazing, and no grazing) were applied in each of the two subtypes on 0.4-ha pastures. Four sheep grazed each subtype at a heavy rate (185 to 198 sheep days / ha) to permit rapid assessment of the retrogressive effects on the plant community. Early summer grazing occurred during a 20-day period starting about July 7; late summer grazing occurred during a 20-day period starting about August 16 each year.

Estimates of total ground cover, yields, and frequencies by species were obtained from 10 randomly located $0.89-\mathrm{m}^{2}$ plots in

\footnotetext{
The authors are range scientist, Intermountain Forest and Range Experiment The authors are range scientist, Intermountain Forest and Range Experiment
Station, Forest Service, U.S. Department of Agriculture, Ogden, Utah, and Horn professor, Department of Range and Wildlife Management, Texas Tech University, Lubbock, Texas.

The support and cooperation of the SEA-Agricultural Research personnel at the U.S. Sheep Experiment Station, Dubois, Idaho, is acknowledged and appreciated. Manuscript received March 10, 1980.
}

each of five 0.04-ha permanent plots in each pasture in 1965, 1967, $1969,1971,1972$, and 1974. The weight-estimate method was used to estimate species yields (Pechanec and Pickford 1937). Utilization was estimated by plant species each year on $30,0.89-\mathrm{m}^{2}$ plots in each 0.4-ha pasture. Photographs were taken in the pastures in the same years that production was measured.

To ascertain the animal response, four 16.2-ha pastures in the pricklygilia subtype were grazed by 87 to 155 mature sheep in early and late summer at a moderate rate. A group of inbred Columbia, Rambouillet, and Targhee ewes, ranging from 2-10 years of age was split randomly and weighed on and off two pastures each period. Ewes were weighed after an overnight fasting period of about 15 hours. The early and late periods began each year at the same time as on the smaller 0.4-ha pastures. The length of the grazing periods was set to maintain a moderate grazing rate between 86 to 99 sheep days/ha. Vegetation on a 0.8-ha portion of each 16.2-ha pasture, selected for comparable topography, vegetation, and distance to water, was sampled similarly to the 0.4-ha pasture in 1965, 1972, and 1974.

Differences in ground cover and herbage weight of species and species categories on the 0.04 -ha permanent plots in each pasture between 1965 and subsequent years were used in an analysis of variance to distinguish vegetation changes between the three treatmenits in a subtype. The study is not replicated in the true statistical design sense, but because site differences between pastures of the same subtype are believed to be negligible, the analysis of variance design is assumed to be correct.

Relative values were calculated to illustrate the vegetation trends because of the natural variation in herbage production between the grazed and ungrazed pastures and between years (Fig. 1). First the air-dry production of a species $(P)$ for each year $(y)$ was expressed as a ratio (V) of the grazed ( $g$ ) to the ungrazed (u) pastures; i.e., Vgy $=\mathrm{Pgy} /$ Puy. Using the ungrazed pasture as a base accounts for yearly differences in production caused by normal fluctuation in temperature and precipitation. The resulting ratios for a grazed pasture for the years 1967, 1969, 1971, 1972, and 1974 were then expressed as a percentage (RV) using 1965 ratios on the grazed pastures as the base; i.e., $R V_{g y}=\left(V_{g y} / V_{g_{1965}}\right)^{*} 100$. This latter step accounts for pasture differences by scaling the data to a

\section{COVER}

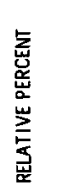

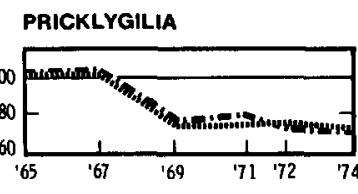

YEAR
BALSAMROOT

YEAR

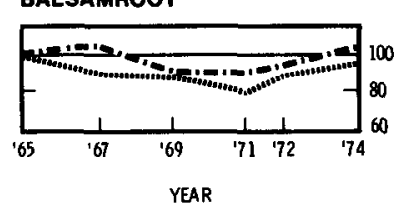

$$
\begin{aligned}
& \text { - Ungrazed } \\
& \text {..ocem! Early summer grazing } \\
& \text {-. - Late summer grazing }
\end{aligned}
$$

Fig. 1. Relative cover on two sagebrush subtypes, 1965 to 1974. 
Table 1. Yield $(\mathrm{kg} / \mathrm{ha})$ and standard deviation of the major species and species categories for the ungrazed pastures on two sagebrush subtypes averaged over a 10-year period.

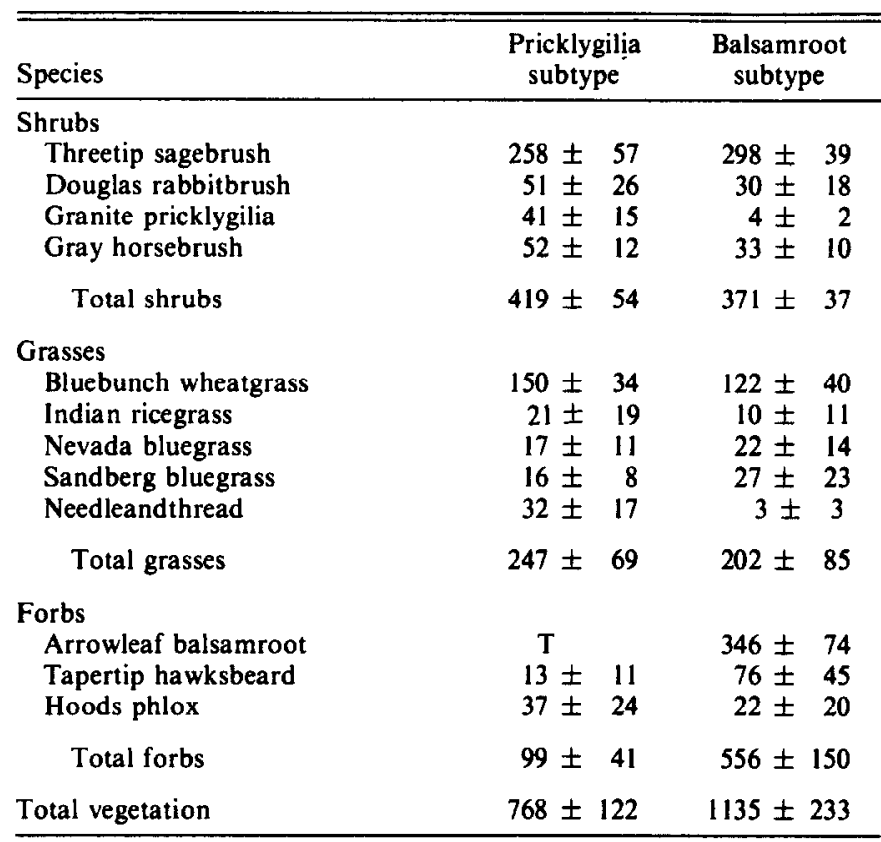

common base of 100 . This technique is similar to that used by Harniss and Murray (1973) in analyzing long-term burning trends on sagebrush-grass range.

\section{Results}

\section{Subtype Differences}

The pricklygilia subtype pastures produced greater yields of shrubs and lower yields of forbs than the balsamroot subtype (Table 1). Threetip sagebrush, Douglas rabbitbrush (Chrysothamnus viscidiflorus), granite pricklygilia, and gray horsebrush (Tetradymia canescens) contributed to the greater yield of shrubs in the pricklygilia subtype. Balsamroot and tapertip hawksbeard (Crepis acuminata) contributed most to the greater yield of forbs in the balsamroot subtype.

The frequency data parallel the yield data with higher rabbitbrush, pricklygilia, and horsebrush and lower balsamroot frequencies in the pricklygilia subtype. Grasses, other than bluebunch

Table 2. Average percentage use of major plant species by sheep in early and late summer on sites with and without balsamroot.

\begin{tabular}{|c|c|c|c|c|}
\hline \multirow[b]{2}{*}{ Species } & \multicolumn{2}{|c|}{ Pricklygilia subtype } & \multicolumn{2}{|c|}{ Balsamroot subtype } \\
\hline & $\begin{array}{l}\text { Early } \\
\text { summer }\end{array}$ & $\begin{array}{l}\text { Late } \\
\text { summer }\end{array}$ & $\begin{array}{l}\text { Early } \\
\text { summer }\end{array}$ & $\begin{array}{l}\text { Late } \\
\text { summer }\end{array}$ \\
\hline $\begin{array}{l}\text { Shrubs } \\
\text { Threetip sagebrush } \\
\text { Douglas rabbitbrush } \\
\text { Granite pricklygilia } \\
\text { Gray horsebrush }\end{array}$ & $\begin{array}{l}1 \pm 11 \\
60 \pm 24 \\
38 \pm 37 \\
18 \pm 19\end{array}$ & $\begin{array}{l}1 \pm 2 \\
49 \pm 18 \\
39 \pm 32 \\
13 \pm 13\end{array}$ & $\begin{array}{r}2 \pm 2 \\
35 \pm 28 \\
27 \pm 31 \\
12 \pm 16\end{array}$ & $\begin{array}{r}3 \pm 16 \\
49 \pm 24 \\
43 \pm 39 \\
15 \pm 21\end{array}$ \\
\hline $\begin{array}{l}\text { Grasses } \\
\text { Bluebunch wheatgrass } \\
\text { Indian ricegrass } \\
\text { Nevada bluegrass } \\
\text { Sandberg bluegrass } \\
\text { Needleandthread }\end{array}$ & $\begin{array}{l}65 \pm 23 \\
62 \pm 27 \\
58 \pm 32 \\
47 \pm 21 \\
70 \pm 16\end{array}$ & $\begin{array}{l}67 \pm 18 \\
57 \pm 20 \\
71 \pm 22 \\
45 \pm 22 \\
71 \pm 22\end{array}$ & $\begin{array}{l}57 \pm 20 \\
49 \pm 32 \\
60 \pm 22 \\
37 \pm 16 \\
46 \pm 34\end{array}$ & $\begin{array}{l}58 \pm 23 \\
57 \pm 29 \\
71 \pm 21 \\
45 \pm 28 \\
68 \pm 23\end{array}$ \\
\hline $\begin{array}{l}\text { Forbs } \\
\text { Arrowleaf balsamroot } \\
\text { Tapertip hawksbeard } \\
\text { Hoods phlox }\end{array}$ & $\begin{array}{l}\overline{56} \pm 16 \\
33 \pm 27\end{array}$ & $\begin{array}{l}\overline{54} \pm 22 \\
34 \pm 24\end{array}$ & $\begin{array}{l}47 \pm 13 \\
42 \pm 16 \\
17 \pm 16\end{array}$ & $\begin{array}{l}39 \pm 18 \\
33 \pm 17 \\
34 \pm 30\end{array}$ \\
\hline
\end{tabular}

'Average utilization under heavy grazing; \pm standard deviation from 1965-1974. wheatgrass (Agropyron spicatum), appear to have varied more in frequency from year to year than did the shrubs or forbs.

Grazing use was generally heavier in the early summer on the pricklygilia subtype than on the balsamroot subtype (Table 2). In late summer, grazing appears to be more similar on both subtypes. Sheep grazed very little sagebrush in either subtype. The shrubs, rabbitbrush and pricklygilia, and most of the forbs were grazed moderately. Grazing was heavy on all the grasses. Bluebunch wheatgrass, Indian ricegrass (Oryzopsis hymenoides), needleandthread (Stipa comata), and Nevada bluegrass (Poa nevadensis) were preferred species and grazed about equally. Sandberg bluegrass (Poa secunda) was generally grazed less than the other grasses, possibly because of its tendency to mature and dry before the summer grazing started.

Ground cover decreased significantly on the pricklygilia subtype and changed little on the balsamroot subtype pastures (Fig. 1).

\section{Heavy Grazing}

\section{Shrubs}

In the pricklygilia subtype no differences in shrub production resulting from early or late grazing could be detected after 10 years (Fig. 2). In the balsamroot subtype, total shrub production

\section{SHRUBS}

\section{PRICKLYGILIA}
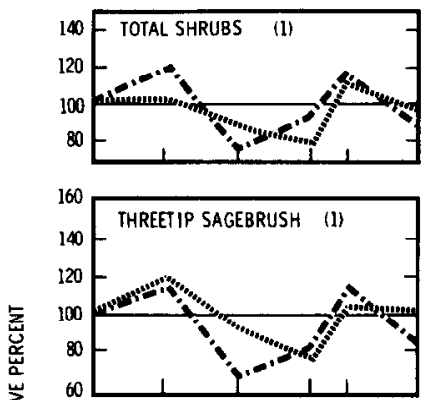$$
\text { 咅 }
$$
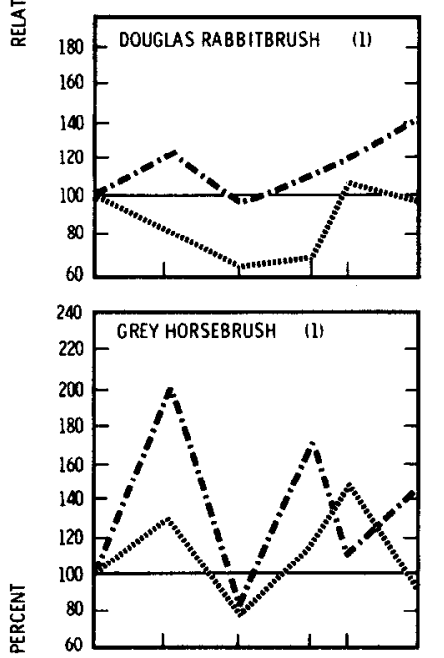

BALSAMROOT
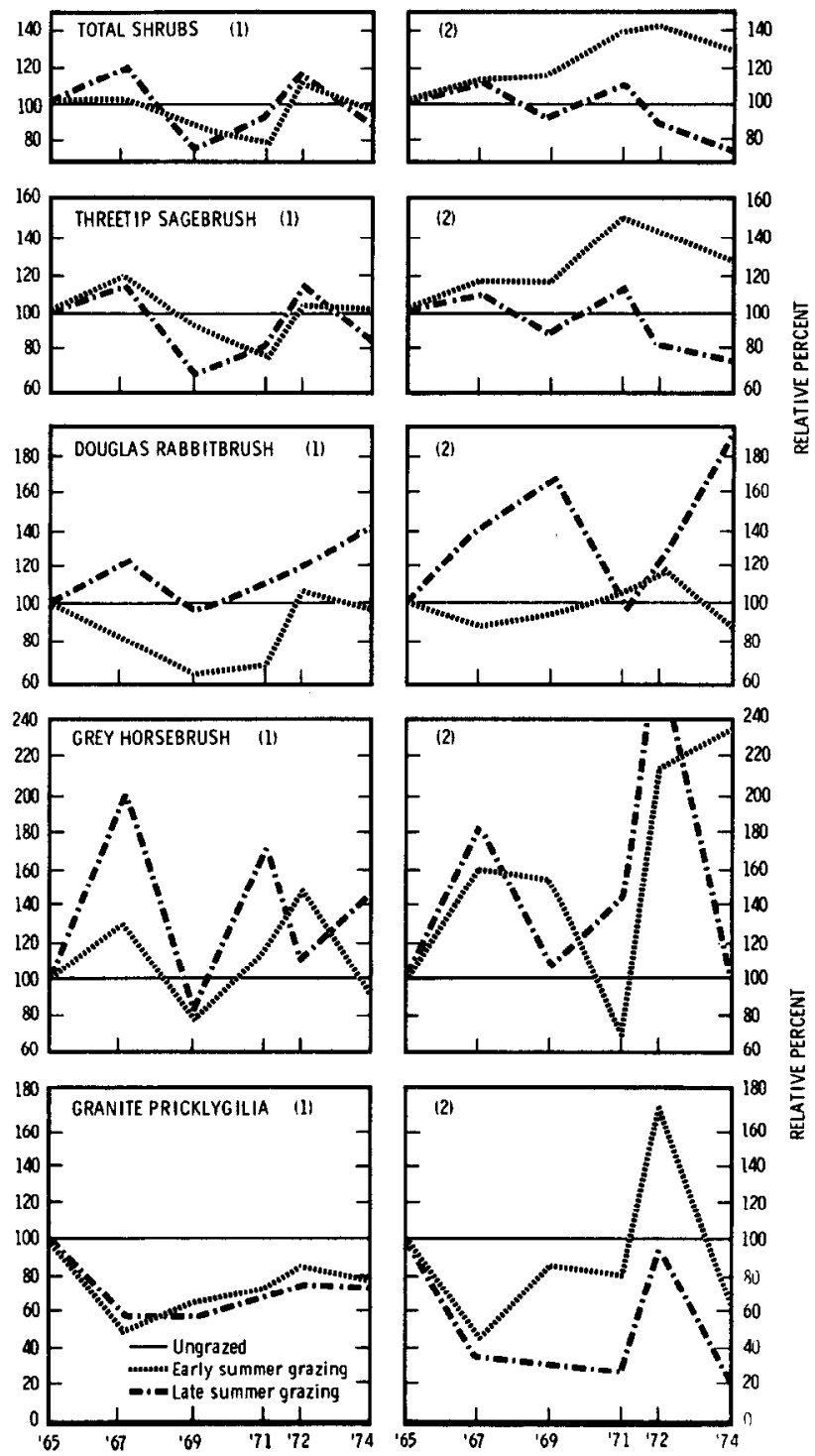

YEAR
Fig. 2. Relative shrub production on two sagebrush subtypes, 1965 to 1974. 
PRICKLYGILIA
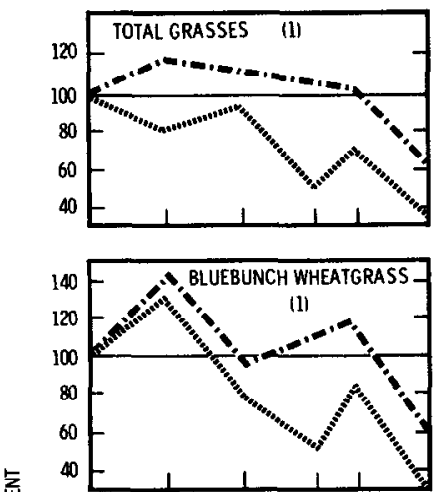

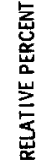

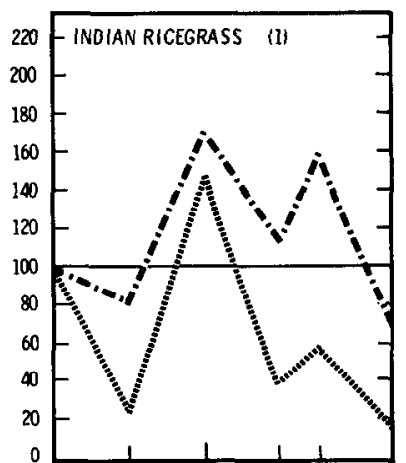

BALSAMROOT
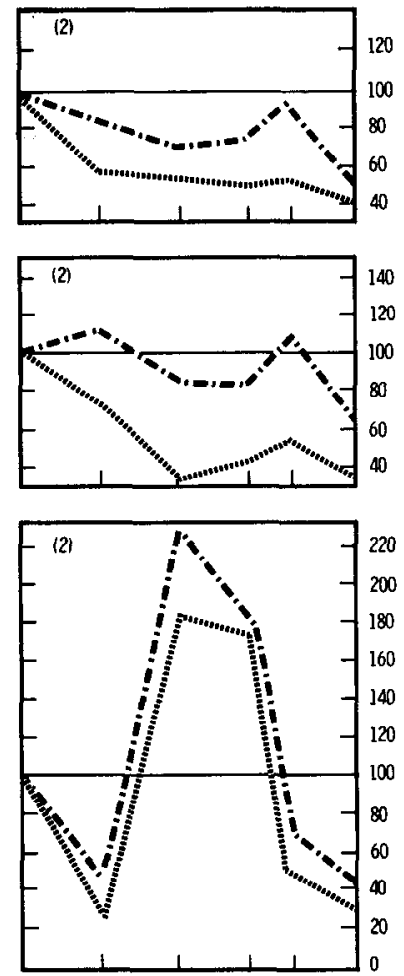

PAICKLYGILIA
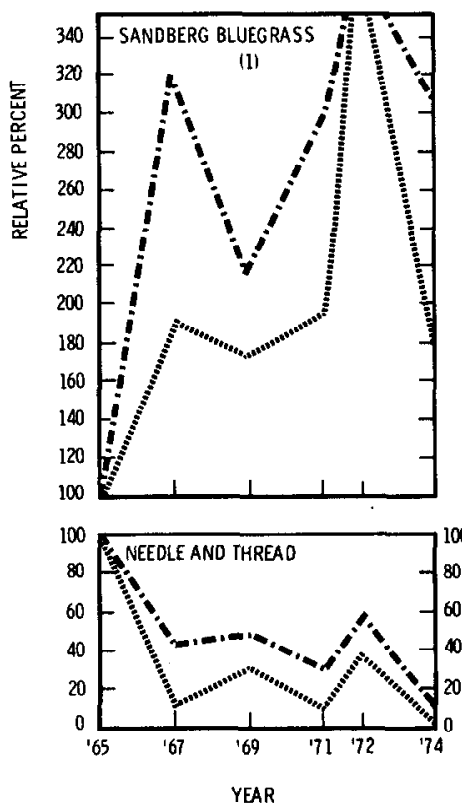

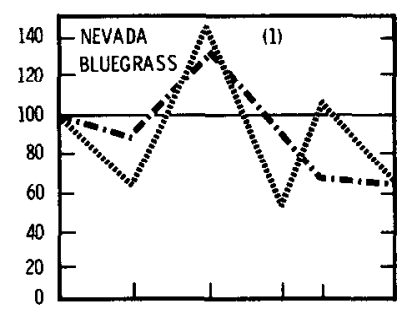

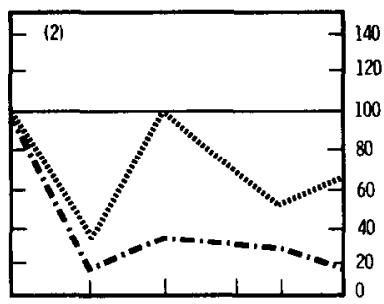

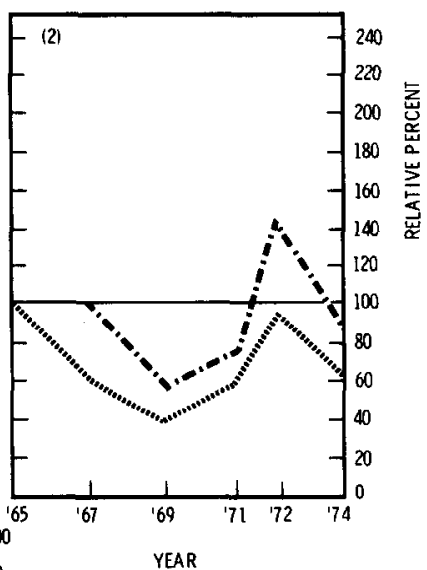

BALSAMROOT

- Ungrazed

......... Early summer grazing -. - Late summer grazing

\section{Fig. 3. Relative grass production on two sagebrush subtypes, 1965 to 1974.}

increased under the early summer grazing treatment but showed no change in late summer after 10 years. Most of the increase was due to the change in threetip sagebrush. Rabbitbrush and horsebrush production was highly erratic on both subtypes; however, until 1971 early summer grazing appeared to depress rabbitbrush production while the trend of horsebrush may have been slightly upward under both early and late summer grazing. A reason for the rabbitbrush return to the 1965 level in 1974 may be that following grazing the first year, new growth in later years occurred within the old grazed crown making it difficult for sheep to utilize.

\section{Grasses}

Total grass production in 1974 was significantly lower than at the beginning of the study for both subtypes on the early summer grazed pastures (Fig. 3). On the balsamroot subtype, production trends of bluebunch wheatgrass, Indian ricegrass, and needleandthread under early summer grazing were lower although not signif-

Table 3. Average weight change (kg/ha) of sheep grazing at a moderate rate on sagebrush-grass range in the summer.

\begin{tabular}{lcccc}
\hline \hline Year & $\begin{array}{c}\text { Sheep } \\
\text { numbers }\end{array}$ & SD/ha & \multicolumn{2}{c}{ Weight change per head } \\
\cline { 3 - 5 } & 113 & 91 & +2.3 & +3.4 \\
1968 & 143 & 94 & +3.2 & -1.8 \\
1969 & 142 & 91 & 0.2 & 0.3 \\
1970 & 155 & 99 & -0.1 & -1.4 \\
1971 & 149 & 96 & +0.9 & +2.0 \\
1972 & 151 & 96 & +1.3 & +0.6 \\
1973 & 87 & 57 & +1.3 & -3.8 \\
1974 & & & +1.3 & -0.2 \\
\hline
\end{tabular}

ISD/ha $=$ sheep days $/$ hectare. icantly so. Under late summer grazing, none of the grasses changed significantly, although the trends appear to be generally downward. Sandberg bluegrass appeared to increase under both seasons of summer grazing in the pricklygilia subtype. In the pricklygilia subtype, bluebunch wheatgrass production decreased under early summer grazing but did not decrease under late summer grazing.

\section{FORBS}

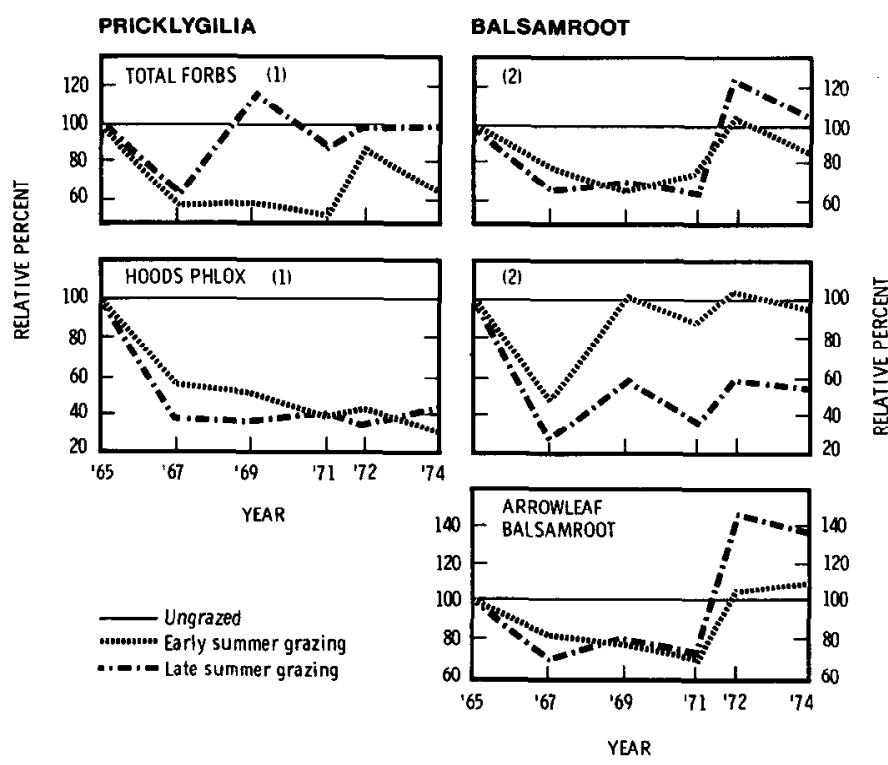

Fig. 4. Relative forb production on two sagebrush subtypes, 1965 to 1974. 


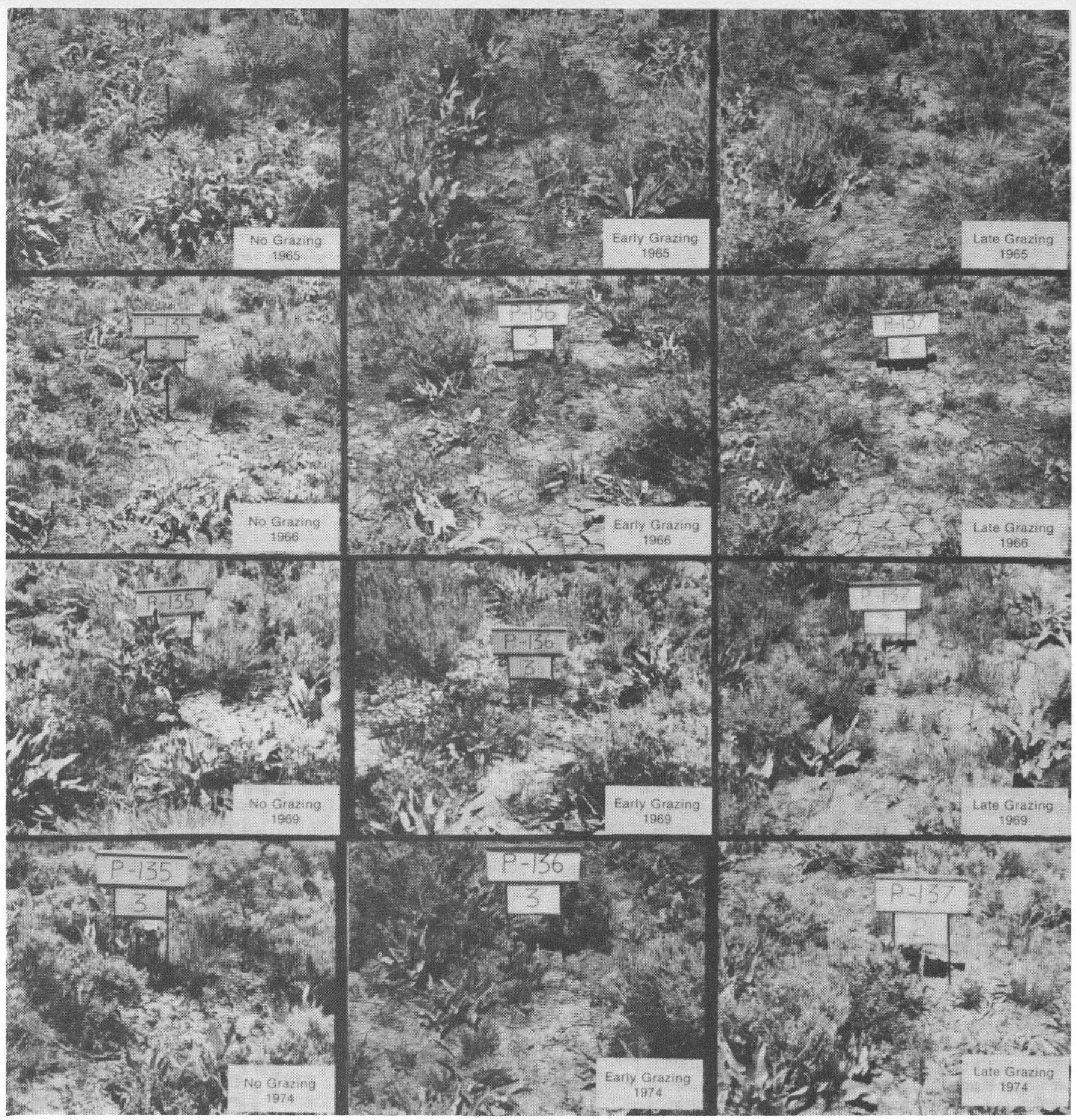

Fig. 5. Ungrazed early summer grazed and late summer grazed pastures from 1965 to 1974 in the sagebrush subtype with balsamroot.

\section{Forbs}

Generally, forb production was not changed significantly by early or late summer grazing in either subtype (Fig. 4). Hoods phlox (Phlox hoodii) was an exception; it decreased significantly under early summer grazing on the pricklygilia subtype.

\section{Moderate Grazing}

A moderate intensity of grazing during either early or late summer did not measurably change the vegetation. Ewe weights indicate that the sheep obtained a maintenance ration during both the early and late summer periods (Table 3) (Price and Harniss 1976). The sheep gained more-or lost less-during early summer than during late summer grazing in 5 out of 7 years. The overall average weight gain was about $1.5 \mathrm{~kg}$ higher in early summer than in late summer.

\section{Discussion}

We selected representative photo plots to depict the results of the grazing treatments from 1965 to 1974 (Fig. 5). Pictures were taken the last week in June and the first week in July.

In the balsam-root subtype, the increased sagebrush yields from early summer grazing and no change from late summer grazing agrees with findings of Mueggler (1950) and Laycock (1967). On this same range their results showed sheep grazing in the spring increased sagebrush and decreased forbs and grasses, whereas grazing in the fall decreased sagebrush and increased forbs and 
grasses. Heavy grazing in our study possibly reduced the deleterious effects on sagebrush and confounded the beneficial effects on the grass and forb classes more than under more moderate grazing, especially in late summer.

The decrease in grass production caused by early summer grazing and the little change caused by late summer grazing agrees with the findings of Pearson (1964) and Wright (1967) that grazing is not very harmful to grasses when they are dormant. For grasses that are not dormant-those that are green and photosynthesizinggrazing continues to be harmful through the hot summer period. During the early summer grazing period, bluebunch wheatgrass and Sandberg bluegrass are generally dormant, while needleandthread, Nevada bluegrass, and Indian ricegrass are not yet dormant. All grasses are dormant during the late summer period.

The use of an ungrazed pasture as a control upon which to base the effects of a grazing treatment needs to be examined. In this study, the protection of the ungrazed pasture was beneficial to plant growth and production until about 1969. After that, some of the species, such as rabbitbrush, bluebunch wheatgrass, and Hoods phlox appeared to decline in yields. Two factors might have contributed to the decline. One, the old dead plant material may have built up until it affected yields by limiting light or reducing soil warming; two, the growth habits of the plants may have changed enough to inhibit yields. This natural decline in the control would tend to mask the deleterious effects of heavy grazing. Perhaps more significant trends would have occurred if the control pasture had been lightly grazed to maintain yields.

The lack of significant change in the forbs, especially balsamroot, may be due to the time of grazing. Balsamroot had flowered and often set seed by the time early grazing began in July. By August, when late grazing began, it had dried and began to shatter. Sheep-grazing after seed set is probably not too harmful and may have assisted in knocking off and planting the seed, contributing to a modest increase in plant numbers to compensate for any reduced production by older plants.

Sagebrush-grass range that is moderately grazed in the summer can maintain ewes whose lambs have been weaned early and yet not be detrimental to the vegetation. In a study comparing these ewes with a comparable set of ewes grazed traditionally on high mountain summer range. Doyle et al. (In press) found little differences in reproduction, longevity. wool production, or lambs marketed.
On the sagebrush-grass range at Dubois, Idaho, a moderate grazing rate in the spring is 30 to 49 sheep days/ha. Sheep can graze about 90 sheep days/ha in the summer without apparent damage to the vegetation. In the fall, up to 148 sheep days/ ha can be grazed with a beneficial effect on the vegetation. An optimal mix of grazing during the spring, summer, and fall should benefit, or at least maintain, productivity of sagebrush-grass.

Use of traditional sagebrush-grass spring-fall range in the summer would be an alternative to using high mountain summer range for sheep grazing if irrigated pastures or supplemental feed were available and lambs could be weaned early. Today, energy cost of feeding lambs in dry lot should be considered versus the relatively inexpensive forage on the summer range. The high sheep losses due to predators and poor herders on summer ranges may, however, balance the feed cost in some areas.

Moderate summer grazing of sagebrush-grass range may provide ranchers and land management agencies with opportunities to maintain sheep numbers, maintain or improve range conditions, and reduce grazing pressure on high mountain summer ranges as well.

\section{Literature Cited}

Doyle, J.J., D.A. Price, H.A. Wright, and D.O. Everson. (In press). Responses of ewes and lambs to different management systems in the mountain summer and sagebrush-grass ranges. J. Range Manage.

Harniss, R.O., and R.B. Murray. 1973. Thirty years of vegetal change following burning of sagebrush-grass range. J. Range Manage. 26:322325.

Laycock, W.A. 1967. How heavy grazing and protection affect sagebrushgrass range. J. Range Manage. 20:206-213.

Mueggler, W.F. 1950. Effects of spring and fall grazing by sheep on vegetation of the Upper Snake River Plains. J. Range Manage. 3:308315.

Pearson, L.C. 1964. Effects of harvest date on recovery of range grasses and shrubs. Agron. J. 56:80-82.

Pechanec, J.R., and G.D. Pickford. 1937. A weight estimate method for the determination of range or pasture productivity. Amer. Soc. Agron. J. 29:894-904.

Price, D.A., and R.O. Harniss. 1976. Response of ewes to grazing sagebrush-grass range during the summer. Soc. Range Manage. 29th Annu. Meet. Abst., p. 15.

Wright, H.A. 1967. Contrasting responses of squirreltail and needleandthread to herbage removal. J. Range Manage. 20:398-400.

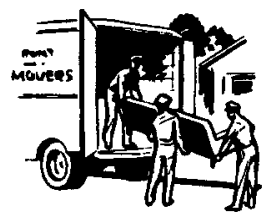

CHANGE OF ADDRESS notices should be sent to the Managing Editor, 2760 West Fifth Ave., Denver, Colo. 80204, no later than the first day of the month of issue. Copies lost due to change of address cannot be replaced unless adequate notice is given. To assure uninterrupted service, provide your local postmaster with a Change of Address Order (POD Form 3575) indicating thereon to guarantee forwarding postage for second-class mail. 